\title{
A Study of Phytodesalination Rate of Water Hyacinth (Eichornia Crassipes) in Brackish Water
}

\author{
Kiridi, E. A and Zalmon, G. P \\ Department of Agricultural and Environmental Engineering, \\ Niger Delta University, Bayelsa State, Nigeria
}

\begin{abstract}
Salinization of freshwater is increasing globally and desalination plants are expensive and energy consuming method to run. The researcher of this paper studied the use of water hyacinth for phytodesalination of brackish water. Ten (10) litres of brackish water (salinity 7.69 ppt) in a plastic trough were placed in three replicates, each containing about $100 \mathrm{~g}$ water hyacinth and studied daily for 6 days. The experiment was conducted to measure the treatment parameters of electrical conductivity (EC), pH, total dissolved solids (TDS) and salinity, thereafter, the treatment means were calculated. Results showed that maximum reductions of most of the water parameter were observed after 3 days of the research and a phytodesalination rates of +0.083 ppt/g/day for EC, $+55.8 \mathrm{ppt/g} /$ day for TDS and $+0.075 \mathrm{ppt} / \mathrm{g} /$ day for salinity were recorded. The water hyacinth started showing signs of nutrient starvation and a reduced rate of desalination after 3 days. This can be addressed by continuously removing spent water hyacinth and re-introducing fresh ones in 3 days intervals until desalination is complete. Anova shows that there was significant difference between control and water hyacinth treatment means at 95 percent confidence level for EC, TDS and salinity. This suggests efficacy of water hyacinth in the desalination of brackish surface water for industrial and other agricultural purposes.
\end{abstract}

Keywords: Phytodesalination, Water Hyacinth, Salinity, Brackish Water.

\subsection{INTRODUCTION}

The world water distribution shows that about $97 \%$ ocean water (seawater and brackish), $3 \%$ freshwater. Of this freshwater, only $1 \%$ are accessible as $79 \%$ and $20 \%$ are ice caps/glacier and groundwater respectively. Brackish water is water that has more salinity than fresh water, but not more salinity than seawater. It can result from the mixing of seawater with fresh water, as in estuaries. Salinization of freshwater streams and rivers is increasing globally through activities such as mining, irrigation, saline wastewater discharge [1], and application of de-icing salts [2].

As reported [3], salinization refers to total concentration of inorganic ions dissolved in water or in soil and is therefore a component of natural waters. Surface water can be classified according to their salt content as follows: freshwater < $0.5 \mathrm{~g} / \mathrm{l}$; oligohaline 0.5 - $4.0 \mathrm{~g} / \mathrm{l}$; mesohaline water 5.0 - $18.0 \mathrm{~g} / \mathrm{l}$; polyhaline water 18.0 - $30.0 \mathrm{~g} / \mathrm{l}$; euhaline water 30.0 - $40.0 \mathrm{~g} / \mathrm{l}$ and hyperhaline water $>40.0 \mathrm{~g} / \mathrm{l}[4]$.

The salinization of surface water can have many different causes. Irrigation and rising groundwater tables were identified as one of the main causes of secondary salinization, especially in the world's arid and semi-arid region where crop production consumes large amounts of water. Since the crop consumes only a fraction of the salt in the water of irrigation, the salt concentrate soil is saltier [5].

The adverse effects of freshwater salinization are severe, including less suitable salinized water for industry, irrigation, freshwater biota and drinking water [6]. High salinity affects plants in two main ways: high concentrations of salts in the soil disturb the capacity of roots to extract water, and high concentrations of salts within the plant itself can be toxic, resulting in an inhibition of many physiological and biochemical processes such as nutrient uptake and assimilation [7, 8, 9, 10]. Together, these effects reduce plant growth, development and survival.

Halophytes are known to be able to grow on salinized soils in coastal and arid regions because of specific salt tolerance mechanism developed during their phylogenetic adaptation. Water hyacinth is reported to be clogging up Lagos waterways. These 
waterways which open to the lagoon are brackish and this invasion by water hyacinth is causing navigational and fishing problems [11].

Accessing freshwater in most communities along estuaries such as the Niger Delta region of Nigeria is difficult as both surface and groundwater around it have higher salinity than acceptable standards, so it is important to desalinate brackish water so that it can be used for farm practices. The desalination of brackish water needs the removal of large amounts of sodium and chlorine. Conventional desalination plants are extremely energy-consuming and expensive to run. Therefore, the use of marine macrophytes for desalination is not only a simpler, easier-to-operate option but also environmentally friendly.

Phytoremediation of various wastewater have been reported by several researchers $[12,13,14,15]$. The objectives of this research are therefore to measure both the salinity level of brackish water and the effects of water hyacinth on the brackish water for 6 days so as to determine its efficacy on desalination.

\subsection{MATERIALS AND METHODS}

\subsection{Experimental site}

The experimental site was open to the laboratory of the Department of Agricultural and Environmental Engineering, Niger Delta University, Wilberforce Island, Bayelsa State, Nigeria. The University is situated in the vegetative mangrove swamp area and has a tropical climate with two seasons: the wet season from March through October and the dry season from November through May.

\subsection{Experimental apparatus and procedure}

The experimental apparatus consists of a plastic water storage tank, a weighing scale, $1000 \mathrm{ml}$ measuring cylinder, salt meter (KADY Salt meter MT-8071), electric conductivity meter/TDS meter/thermometer (LT Lutron YK-22CT) and pH meter (Testo 206-PH3). Brackish water on was obtained from Ozuboko River $\left(4.7715913^{\circ} \mathrm{N}, 7.0427778^{0} \mathrm{E}\right)$ in Abuloma community in Rivers State, Nigeria and transported down to the experimental site. Some of the physico-chemical characteristics of the brackish are presented in Table 1

The experiment was conducted as described by [12]. Appropriate quantities of water hyacinth (Eichornia crassipes) in their natural habitats were carefully harvested from within and around Amassoma in Southern Ijaw Local Government Area in Bayelsa State. Approximately $100 \mathrm{~g}$ of the water hyacinth were then placed in three replicates of plastic trough containing 10 litres of brackish water and a control. Each trough was analysed on a 24 hrs interval for 6 days on the desalination efficacy of the water hyacinth on the selected water parameters which were $\mathrm{pH}$, electrical conductivity (EC), total dissolved solids (TDS) and salinity

\subsection{RESULTS AND DISCUSSIONS}

Results show that the $\mathrm{pH}$ of the water hyacinth treatment means ranged from 5.84 to 6.79 and water hyacinth was able to gradually reduce the concentrations of EC and TDS within the first three days of its introduction, thereafter, an increase in concentration levels was observed which

Table 1. Some physico-chemical characteristics of the brackish water

\begin{tabular}{ll}
\hline Parameters & Value \\
\hline pH & 6.1 \\
\hline Conductivity (S/m) & 13.19 \\
\hline Temperature $\left({ }^{\mathbf{0}} \mathbf{C}\right)$ & 27 \\
\hline T.D.S (ppt) & 8801 \\
\hline Salinity (ppt) & 7.690 \\
\hline
\end{tabular}


International Journal of Advances in Scientific Research and Engineering (ijasre), Vol 6 (1), January-2020

Table 2. Mean effects of the water hyacinth treatment on some physicochemical characteristics of the brackish water for the 6 days intervals

\begin{tabular}{|c|c|c|c|c|c|c|c|}
\hline \multirow{2}{*}{$\begin{array}{c}\text { Brackish } \\
\text { water } \\
\text { parameters }\end{array}$} & \multicolumn{5}{|c|}{ Phytodesalination Period (Days) } & \multirow[b]{2}{*}{5} & \multirow[b]{2}{*}{6} \\
\hline & $\mathbf{0}$ & 1 & 2 & 3 & 4 & & \\
\hline $\mathrm{pH}$ & 6.10 & 6.76 & 6.37 & 5.84 & 6.60 & 6.47 & 6.38 \\
\hline $\mathrm{EC}(\mathrm{S} / \mathrm{m})$ & 13.19 & 12.50 & 10.85 & 10.69 & 11.55 & 11.41 & 11.69 \\
\hline Temp $\left({ }^{0} \mathrm{C}\right)$ & 27 & 29 & 30 & 26 & 27 & 31 & 30 \\
\hline TDS (ppt) & 8801 & 8377 & 7200 & 7127 & 7700 & 7600 & 7800 \\
\hline Salinity (ppt) & 7.69 & 7.2 & 6.34 & 5.45 & 5.08 & 4.94 & 4.60 \\
\hline
\end{tabular}

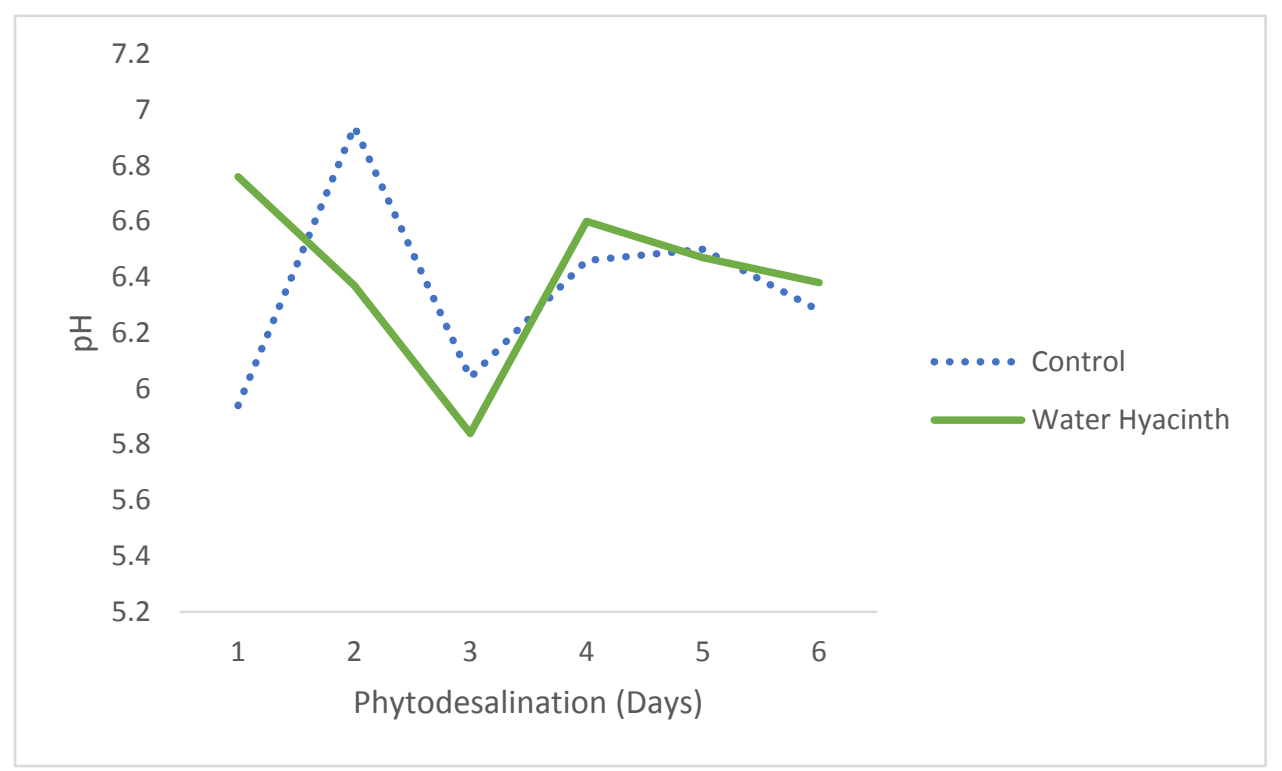

Figure 1. Comparison between control and water hyacinth treatment means with respect to $\mathrm{pH}$ 


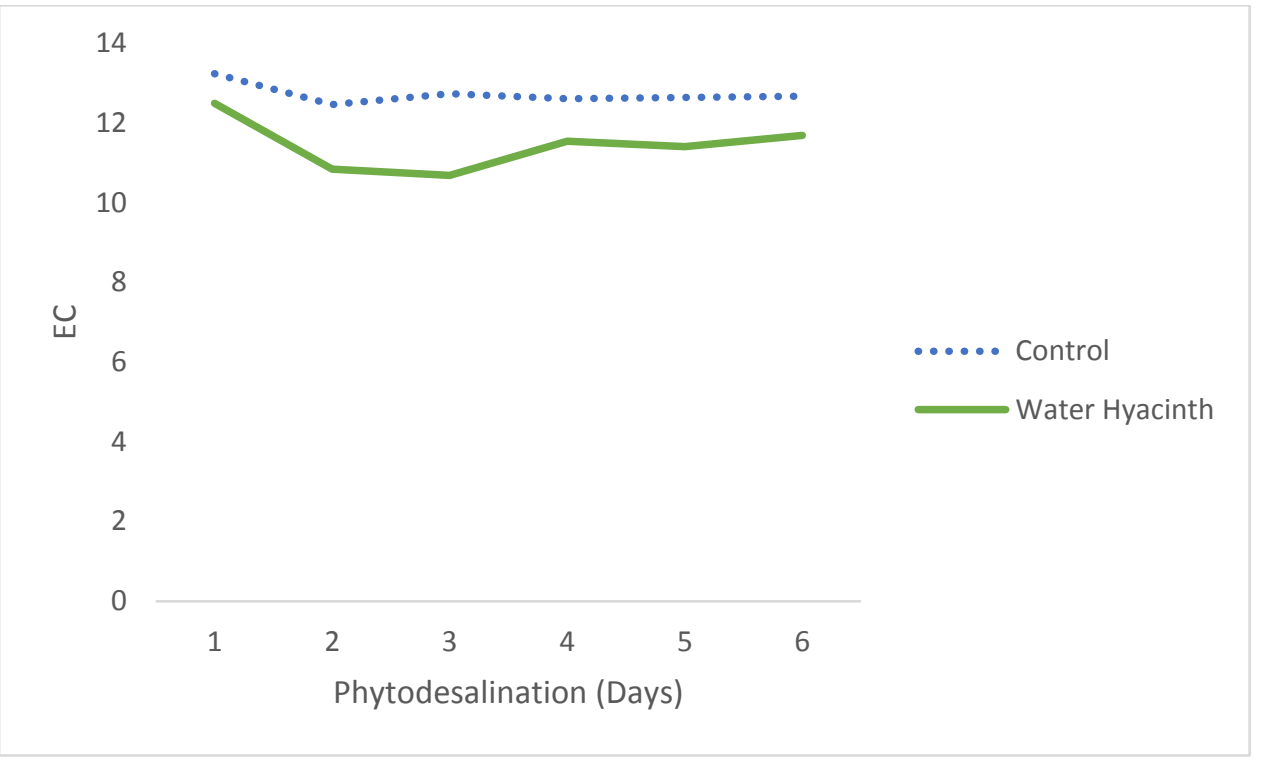

Figure 2. Comparison between control and water hyacinth treatment means with respect to EC

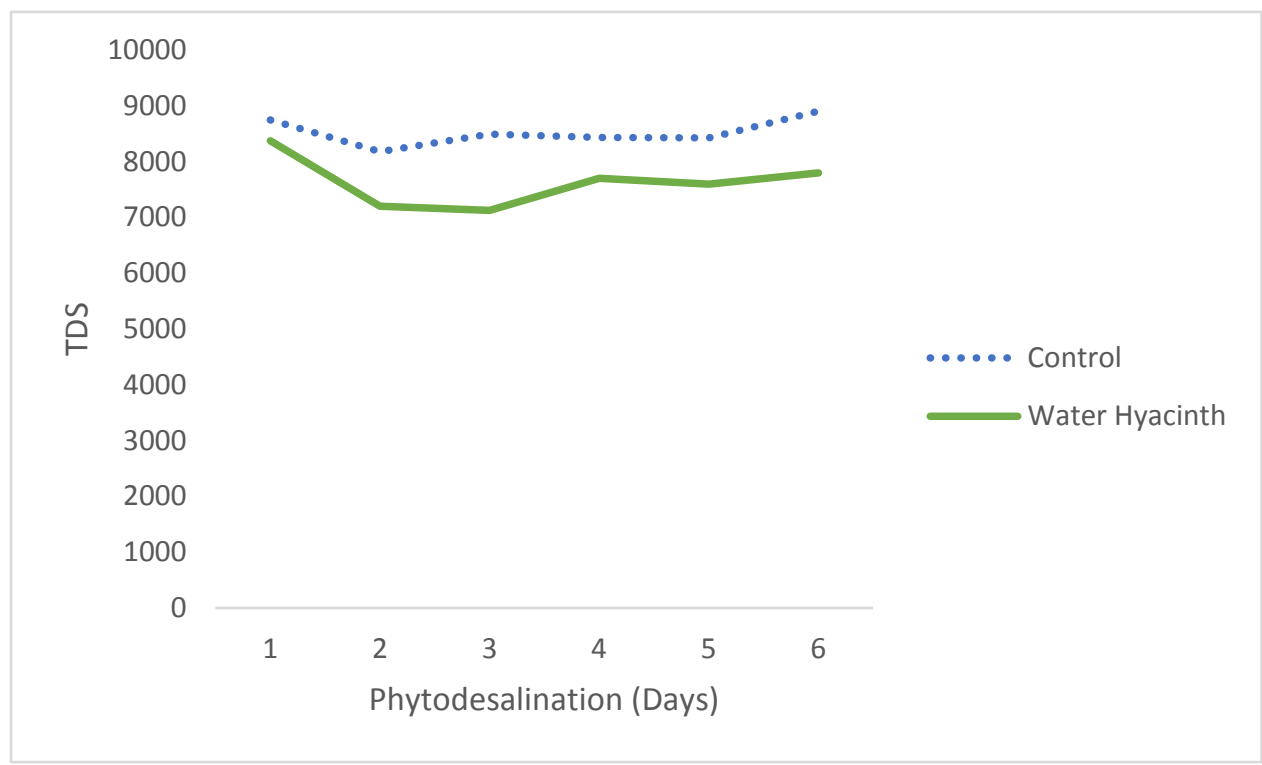

Figure 3. Comparison between control and water hyacinth treatment means with respect to TDS 


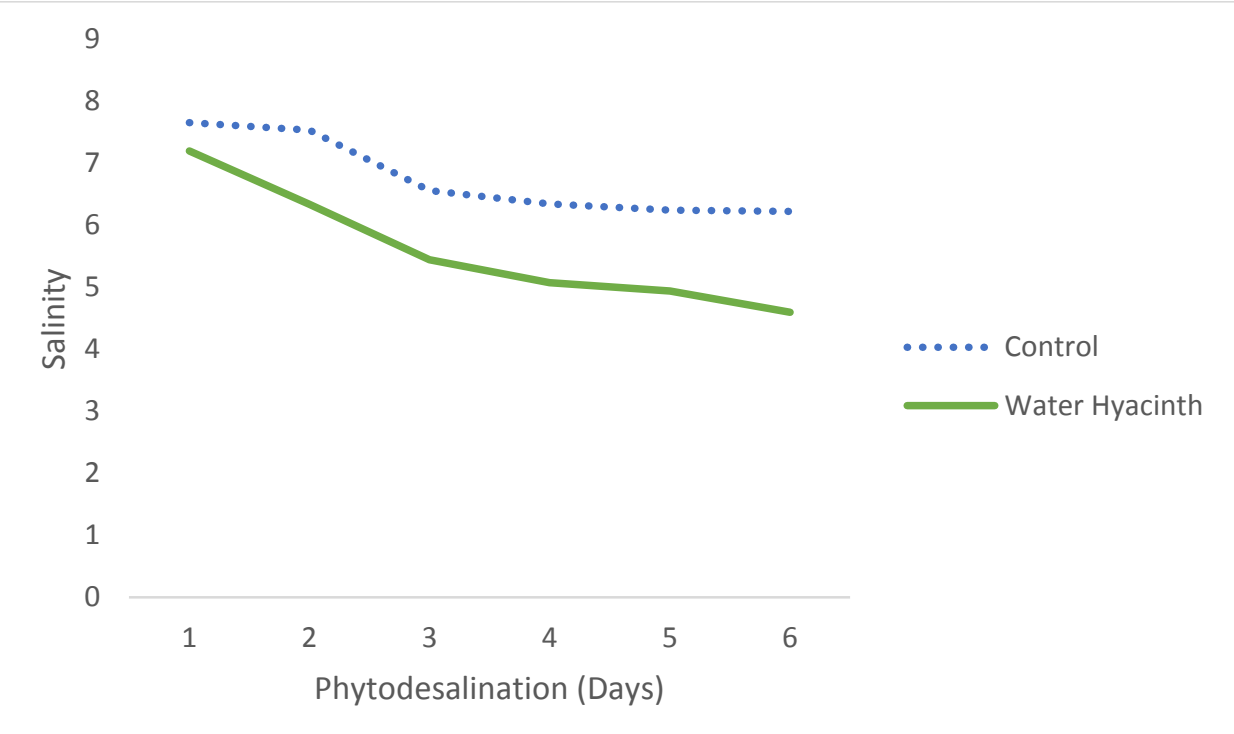

Figure 4. Comparison between control and water hyacinth treatment means with respect to salinity

Table 3. Phytodesalination rates by water hyacinth treatment of the brackish water after 3 days

\begin{tabular}{|c|c|c|c|c|c|c|c|c|}
\hline Parameter & $\begin{array}{c}* \mathbf{P I} \\
\text { (days) }\end{array}$ & Treatment & Influent & Effluent & Red & ion & $\begin{array}{c}\text { Desalination } \\
\text { rate/day }\end{array}$ & $\begin{array}{c}\text { Desalination } \\
\text { rate/g/day }\end{array}$ \\
\hline pH & 3 & $* * \mathrm{WH}$ & 6.10 & 5.84 & +0.26 & +4.3 & +0.09 & +0.009 \\
\hline $\mathrm{EC}(\mathrm{S} / \mathrm{m})$ & 3 & WH & 13.19 & 10.69 & +2.5 & +20.0 & +0.83 & +0.083 \\
\hline TDS (ppt) & 3 & WH & 8801 & 7127 & +1674 & +19.0 & +558 & +55.8 \\
\hline $\begin{array}{c}\text { Salinity } \\
\text { (ppt) }\end{array}$ & 3 & WH & 7.69 & 5.45 & +2.24 & +29.1 & +0.75 & +0.075 \\
\hline
\end{tabular}

$* \mathrm{PI}=$ Phytodesalination interval; $* * \mathrm{WH}=$ Water Hyacinth

Table 4. Anova summary between the control and water hyacinth treatment on the brackish water

\begin{tabular}{ccccccccc}
\hline Parameter & $\begin{array}{c}\text { Control } \\
\text { mean }\end{array}$ & $\begin{array}{c}\text { Treatment } \\
\text { mean }\end{array}$ & $\begin{array}{c}\text { Control } \\
\text { variance }\end{array}$ & $\begin{array}{c}\text { Treatment } \\
\text { variance }\end{array}$ & $\begin{array}{c}\text { F } \\
\text { (Cal) }\end{array}$ & $\begin{array}{c}\text { F } \\
\text { (Crit) }\end{array}$ & $\begin{array}{c}\text { P (value) } \\
* \text { Treatment } \\
\text { Remarks }\end{array}$ \\
\hline pH & 6.36 & 6.40 & 0.13024 & 0.097867 & 0.049 & 4.96 & 0.828598 & NS \\
\hline EC(S/m) & 12.73 & 11.45 & 0.069747 & 0.421857 & 20.15 & 4.96 & 0.001162 & S \\
\hline TDS (ppt) & 8531.17 & 7634 & 66619.37 & 206104.4 & 17.71 & 4.96 & 0.001805 & $\mathrm{~S}$ \\
\hline $\begin{array}{c}\text { Salinity } \\
\text { (ppt) }\end{array}$ & 6.77 & 5.60 & 0.43347 & 0.967217 & 5.80 & 4.96 & 0.036825 & $\mathrm{~S}$ \\
\hline
\end{tabular}

*Treatment Remarks: $\mathrm{S}=$ Significant; NS = Not significant 
indicated re-introduction of the EC and TDS (Table 2) but a continuous reduction of the concentration levels of salinity. Figures 1 to 4 show the comparisons between the effects the water hyacinth treatment with respect to the selected water parameters and control. It was observed that there was an increase in concentration levels after 3 days for pH, EC and TDS except salinity.

Table 3 show the physicochemical reduction by water hyacinth of the brackish water after 3 days of the research. A desalination rates of $+0.083 \mathrm{ppt} / \mathrm{g} /$ day for EC, $+55.8 \mathrm{ppt} / \mathrm{g} /$ day for TDS and $+0.075 \mathrm{ppt} / \mathrm{g} /$ day for salinity were observed. The water hyacinth started showing signs of nutrient starvation and a reduced rate of desalination. This is because the essential nutrients for plant survival in brackish water are limited.

A summary of the analysis of variance (Anova) between the control and water hyacinth treatment on the brackish water show that with the exception of $\mathrm{pH}, \mathrm{F}$ (cal) is greater than $\mathrm{F}$ (crit) and the $\mathrm{P}$ value is $<0.05$, therefore it can be concluded statistically that there was a significant difference between water hyacinth treatment and the control for EC, TDS and salinity (Table 4).

\subsection{CONCLUSIONS AND RECOMMENDATIONS}

The conclusions of this research are:

1. Water hyacinth was able to reduce the concentration levels of the selected brackish water parameter

2. The maximum reduction of concentration was at day 3 of the research except for salinity

3. The concentration levels of the selected brackish water parameter began to increase after day 3 except for salinity

The recommendation for this research is that the water hyacinth should be removed after 3 days to prevent re-introduction of the absorbed salts and fresh water hyacinth be introduced to continue the phytodesalination process in 3 days interval until desalination is complete.

The research has shown that phytodesalination is a cheaper alternative and should be embraced in the desalination of brackish surface water.

\section{REFERENCES}

[1] Williams, W. D. (2001). Anthropogenic salinization of inland waters. Hydrobiologia, 466, 329 -337.

[2] Kaushal, S. S., Groffman, P. M., Likens, G. E., K. T. Belt, K. T., Stack, W. P., V. R. Kelly, V. R., L. E. Band, L. E and Fisher, G. T. (2005). Increased salinization of fresh water in the Northeastern United States. Proceedings of the National Academy of Sciences of the United States of America 102:13517- 13520.

[3] William, W. D and Sherwood, J (1994) Definition and measurement of salinity in salt lakes. International Journal of Salt Lake Research.3 (1) 53-63

[4] Vernice System (1959). The final resolution of the symposium on the classification of brackish waters. Archives Oceanography and Limnology. 11 (Suppl). 243-248

[5] Lerotholi, S., Palmer, C. G and Rowntree, K (2004). Bioassessment of a River in a Semi-arid Agricultural Catchment, Eastern Cape In. Proceedings of 2004 Water Institute of South Africa (WISA) Biennial Conference, Cape Town S.A. pp 338-344.

[6] Williams, W. (1987). Salinization of rivers and streams: an important environmental hazard. Ambio Ambocx, 16(4), 180-185.

[7] Hasegawa, P. M., Bressan, R. A., Zhu, J. K., and Bohnert, H. J. (2000). Plant cellular and molecular responses to high salinity. Annual Review of Plant Physiology and Plant Molecular Biology, 51, 463-499

[8] Munns, R. (2002). Comparative physiology of salt and water stress. Plant, Cell \& Environment, 25(2), $239-250$.

[9] Munns, R., Schachtman, D., and Condon, A. (1995). The Significance of a Two-Phase Growth Response to Salinity in Wheat and Barley. Functional Plant Biology, 22(4), 561-569.

[10] Munns, R., and Tester, M. (2008). Mechanisms of salinity tolerance. Annual Review of Plant Biology, 59, 651-681.

[11] https://www.vanguardngr.com/2019/06/water-hyacinths-plague-lagos-waterways/

[12] Kiridi, E. A and Ogunlela, A, O (2016). Phytoremediation rates of water hyacinth in an aquaculture effluent hydroponic system. International Journal of Environmental, Chemical, Ecological, Geological and Geophysical Engineering. Vol 10, No 3. pp 361-365.

[13] Jamuna, S and Noorjahan, C. M. (2009) Treatment of sewage wastewater using water hyacinth Eichornia sp and its reuse for fish culture. Toxicol. Int. Vol 16. No 2 pp 103-106. 
[14] Snow, A. M and Ghaly, A. E (2008) A comparative study of the purification of aquaculture wastewater using water hyacinth, water lettuce and parrot's feather. American Journal of Applied Sciences. Vol. 5(4): 440-453.

[15] Jung, K.H (2002) Treatment of wastewater from livestock rearing with aquatic plants. Tech Bulletin. National Livestock Research Institute (NLRI) Republic of Korea. 